\title{
Characterization of a VHS virus genotype III isolated from rainbow trout (Oncorhychus mykiss) at a marine site on the west coast of Norway
}

\author{
Henrik Duesund, Stian Nylund, Kuninori Watanabe, Karl F Ottem, Are Nylund
}

\begin{abstract}
Background: Norwegian production of rainbow trout (Oncorhynchus mykiss) has been without any outbreaks of VHS for many years until the disease emerged in a farm in western Norway in November 2007. The fish were, in addition to VHS virus, positive for gill chlamydia-like bacteria, Flavobacterium psychrophilum, and a microsporidian. A new VHS virus genotype III was isolated from the fish in RTgill-W1 cells and the complete coding region (11,065 nucleotides) was sequenced. This virus was also used in a challenge experiment to see if it could cause any mortality in rainbow trout in sea water.

Results: This is the first time a nearly complete sequence of a genotype III virus isolate has been presented. The organization of the genes is the same as in the other VHS virus genotypes studied (GI and GIV). Between the ORFs are nontranslated regions that contain highly conserved sequences encompassing the polyadenylation signal for one gene, and the putative transcription initiation site of the next gene. The intergenic regions vary in length from $74 \mathrm{nt}$ to $128 \mathrm{nt}$. The nucleotide sequence is more similar to genotype I isolates compared to isolates from genotype II and IV. Analyses of the sequences of the $\mathrm{N}$ and $\mathrm{G}$ protein genes show that this new isolate is distinct from other VHS virus isolates and groups closely together with isolates from genotype III. In a challenge experiment, using intraperitoneal (ip) injection of the isolate, co-habitation with infected fish, and bath challenge, mortalities slightly above $40 \%$ were obtained. There was no significant difference in mortality between the bath challenged group and the ip injected group, while the mortality in the co-habitation group was as low as 30\%.

Conclusions: All VHS virus isolates in genotype III are from marine fish in the North East Atlantic. Unlike the other known genotype III isolates, which are of low virulence, this new isolate is moderately virulent. It was not possible to detect any changes in the virus genome that could explain the higher virulence. A major problem for the study of virulence factors is the lack of information about other genotype III isolates.
\end{abstract}

\section{Background}

Viral haemorrhagic septicaemia virus (VHSV) is an enveloped, single stranded, negative-strand RNA virus belonging to the genus Novirhabdovirus, family Rhabdoviridae [1]. The VHS virus genome consists of approximately $11 \mathrm{k}$ nucleotides and six genes encoding nucleocapsid- $(\mathrm{N})$, phospho- $(\mathrm{P})$, matrix- $(\mathrm{M})$, glyco(G), non-structural- (Nv) and RNA polymerase (L) protein. Based on phylogenetic analysis of the N, P, G and $\mathrm{Nv}$ protein genes the VHS virus isolates have been divided into four different genotypes; VHS virus

\footnotetext{
* Correspondence: are.nylund@bio.uib.no

Department of Biology, University of Bergen, Thormohlensgt 55, 5020 Bergen, Norway
}

genotypes I, II, III and IV [2-7]. The third VHS virus genotype (III) represents isolates from marine fish species in Kattegat, Skagerrak and the North Sea [8] and a member of this genotype was in the autumn of 2007 associated with about $10 \%$ mortality in a rainbow trout farm in western Norway $[9,10]$. VHS virus genotype III has been found in eel (Anguilla anguilla), cod (Gadus morhua), herring (Clupea harengus), sprat (Sprattus sprattus), haddock (Melanogrammus aeglefinus), Norway pout (Trisopterus esmarkii), poor cod (Trisopterus minutus), blue whiting (Micromesistius poutassou), withing (Merlangius merlangus), turbot (Scophthalmus maximus), greenland halibut (Reinhardtius hippoglossoides) and lesser argentine (Argentina sphyraena) [cf 
$[3,5,8,11]]$. The outbreak of VHS in Norway is the first time an isolate belonging to genotype III is found in rainbow trout.

According to existing literature challenge of rainbow trout with the VHS virus, genotype III, should not result in any significant mortality [12]. However, it is to be expected that viruses which enter into farmed populations of fish may show some virulence and possibly cause mortality. It has been shown that VHS virus belonging to genotype III may cause mortality when challenging turbot [13-15] and halibut [16], which suggests that the susceptibility of the host species is also important for the expected mortality. This has also been observed for other viruses isolated from fish $[17,18]$. A challenge experiment on rainbow trout fingerlings (10.1 grams) in fresh water, using a VHS virus isolate type III from the same outbreak as the isolate used in this study, has already been carried out resulting in mortality after immersion and injections of $70 \%$ and $100 \%$, respectively [9]. However, this genotype III VHS virus is a purely marine virus and experiment on fingerlings in fresh water may not be representative for the susceptibility of larger rainbow trout in sea water, and the resulting mortality in sea water cannot be predicted based on this challenge experiment.

The aim of the present study is to see if this VHS virus genotype III with the first completely characterized coding region may cause any mortality when challenging rainbow trout in full sea water. The genome of this isolate will be compared with partly sequenced VHS virus, genotype III, and completely sequenced coding regions and intergenic regions of other VHS virus, genotypes I and IV. Such a comparison may also give clues as to which changes in the genome may influence the virulence or ability to cause mortality in rainbow trout populations.

\section{Results}

\section{Genome of isolate FA28.11.07}

The first genome of a VHS virus in genotype III, strain FA28.11.07, containing all protein coding sequences (CDS) and intergenic regions (ITRs), has been sequenced (accession no: EU481506). The sequence is 11,065 nucleotides (nt) long and contains six open reading frames (ORF) in the order 3'-N-P-M-G-NV-L-5'. This arrangement is identical to what has been found for other, fully sequenced, VHS virus isolates in genotype I $[19,20]$ and IV (accession no: AB490792). Between the ORFs are nontranslated regions that include highly conserved sequences encompassing the polyadenylation signal for one gene, and the putative transcription initiation site of the next gene. An alignment of the conserved nontranslated sequences is shown in Figure 1. The intergenic regions vary in length, from $74 \mathrm{nt}$ between the G and NV ORFs, to 128 nt between the $\mathrm{NV}$ and L ORFs. This is consistent with what has been found for VHS virus isolates in other genotypes except that the length of the intergenic sequences in genotype IV isolates are slightly different. The polyadenylation signal is also present after the ORF of the L protein (21 nt downstream), but the sequence (aga ttg aaa aaa a) is slightly different from that found in the intergenic regions.

Characteristics of the different protein coding genes and their deduced ORFs are listed in table 1 . When comparing the amino acid identity of the deduced proteins of isolate FA28.11.07 (genotype III) to that of fully or partially sequenced VHS virus isolates, all proteins share a higher identity to the genotype I isolates than isolates from genotypes II and IV (table 2). The only genes sequenced from other genotype III isolates are those coding for the G and NV proteins and these show the highest identity to FA28.11.07. The short ORF (366 $\mathrm{nt})$, located between the $\mathrm{G}$ and $\mathrm{L}$ protein, encodes the $\mathrm{NV}$ protein which is the most variable protein based on amino acid (aa) sequences. The variation is found throughout the aa sequence, but the latter 14 aa are distinctly different in the three genotypes I, III and IV (Figure 2). Most of the variation in the nucleoprotein (N) of VHS virus isolates, comparing genotypes I, III and IV, is found between aa 37 - 132 and among the last 37 aa in the peptide, avoiding the conserved RNA binding domain suggested to be in the middle region of the protein. The aa variation in the $\mathrm{P}$ protein, among VHS virus isolates, is mainly in the first third of the protein, while there is little variation in the $M$ protein.

Variation in aa sequence of the $G$ protein is found throughout the length of the protein, but with little variation in the putative transmembrane regions. The

$$
\begin{array}{lll}
\text { N-P } & \text { AgAtAGAAAAAAA } & \text { TGGCACGATtAT } \\
\text { P-M } & \text { AGATAGAAAAAAA } & \text { CGGCACGACTGT } \\
\text { M-G } & \text { AGATAGAAAAAAA } & \text { TGGCACATTTGT } \\
\text { G-N } & \text { AGATAGAAAAAAA } & \text { TGGCACTTCTTT } \\
\text { NV-L } & \text { AGATAGAAAAAAA } & \text { TGGCACTTTTGT }
\end{array}
$$

Consensus AGATAGAAAAAAA YGGCACDWYTDT

Figure 1 Comparison of the conserved sequence parts of the intergenic regions within the VHS virus isolate, FA28.11.07, genome. The sequences between the genes $N$ and $P(N-P), P$ and $M(P-M), M$ and $G(M-G), G$ and NV (G-NV), NV and $L(N V-L)$ are listed in message sense along with the consensus sequence. The sequences consist of a polyadenylation signal and a putative transcription initiation site, respectively. 


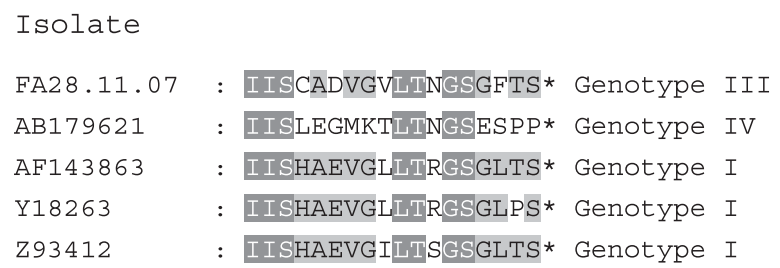

Figure 2 The CO end (last 18 amino acids) of the deduced NV protein sequence from VHS virus isolates belonging to genotypes I, III and IV.

TMpred program http://www.ch.embnet.org/software/ TMPRED_form.html was used for prediction of transmembrane regions and orientation in the $G$ protein of FA28.11.09. The most strongly supported model suggested transmembrane regions between aa $1-18$ and aa 462 - 483 where the latter has the highest support.

The last ORF (1984 aa) in the VHS virus genome is the large (L) protein that encodes the RNA-dependent RNA polymerase. The L protein from FA28.11.07 is highly similar to the other L protein genes sequenced from other VHS virus isolates, with the exception of one isolate of genotype I, isolate FR-07-71 (Accession nos: AJ233396 and AJ009814) from France. The conserved domains III and IV containing the four major motifs A, B, C and D localized between aa 566 and 790 [cf $[21,20]]$ are also present in isolate FS28.11.09. A putative ATP biding site, with sequence GEGVRG - (20 aa) - $\mathrm{K}$ in position aa 1223 to aa 1249 , is present in FA28.11.07 and the genotype I isolates with the exception of isolate FR-07-71 from France. The ATP binding site in FR-07-71 and isolates in genotype IV are GEGVRR - (20 aa) - K and GEGIRG - (20 aa) - K, respectively.

Ten amino acid residues that may play a role in the determination of virulence in genotype I isolates have been identified [19] (table 3). Compared to the genotype I isolates, the VHS virus isolate FA28.11.09 genotype III from rainbow trout in Norway, share 2 and 6 amino acids with the avirulent and virulent strains, respectively. No information is available about the N, P and $\mathrm{L}$

Table 1 VHSV isolate FA28.11.07 genome transcription units and deduced protein products.

\begin{tabular}{cccccccc}
\hline & \multicolumn{3}{c}{ mRNA features (nt) } & \multicolumn{4}{c}{$\begin{array}{c}\text { Deduced protein features } \\
\text { (aa) Calculated }\end{array}$} \\
\hline Gene & Length & 5'UTR $^{\prime}$ ORF & 3'UTR & Length & Mr & pl \\
NP & 1368 & 113 & 1212 & 43 & 404 & 44.1 & 5.2 \\
P & 761 & 58 & 666 & 37 & 222 & 24.5 & 8.5 \\
Matrix & 742 & 83 & 603 & 56 & 201 & 22.3 & 9.3 \\
G & 1610 & 35 & 1521 & 54 & 507 & 57.0 & 6.5 \\
NV & 423 & 23 & 366 & 34 & 122 & 13.6 & 5.4 \\
L & 6086 & 97 & 5952 & 37 & 1984 & 224.4 & 7.6 \\
\hline
\end{tabular}

proteins from other genotype III isolates. It has also been suggested that two regions, related to fusion activity, within the $\mathrm{G}$ protein may play a role in determination of virulence [22]. The VHS virus isolate, FA28.11.09, from rainbow trout in Norway shares six out of seven amino acids, believed to be important for determination of virulence, with the highly virulent FR07-71 strain (table 4). However, so do all other VHS virus genotype III isolates (see accession numbers in table 2).

\section{Phylogeny}

Analyses of the relationship of the VHS virus isolate FA28.11.07, based on nucleotides of the complete open reading frame (ORF) of the $\mathrm{N}(1215 \mathrm{nt})$ and $\mathrm{G}$ (1524 nt) proteins, show that this isolate belong to genotype III (Figures 3 and 4). The closest relatives, based on the ORF of the G protein, are VHS virus isolates from Atlantic cod, Norway pout, and haddock collected in the North sea and herring and turbot collected in Skagerrak and Ireland, respectively. The genotype, GIII, constitutes a sister group to GI in both phylogenies. The nucleotide sequence of the $G$ protein from FA28.11.07 is identical to that published (Accession no: EU547740) by Dale et al [9]. The VHS virus from herring ( $\mathrm{CH} 15.02 .08)$, collected in the mouth of Storfjorden, belongs to genogroup Ib. The rainbow trout isolate from Norway (FA28.11.07) is the only fully sequenced member of the GIII. The phylogeny based on the nucleotide sequences of the ORF of the $\mathrm{N}$ protein shows stronger support values compared to a similar analysis using the $G$ gene, however, this could be a result of the choice of isolates and the number of isolates included in the two phylogenies.

\section{Challenge experiment}

The rainbow trout used in the challenge experiment, came from fresh water and were put directly in full sea water, where they suffered some mortality (8.8\%) during the acclimatization period. Most of the mortality seemed to be due to poor smoltification, but bacteria (Vibrio spp. and Alivibrio spp.) were isolated from a few fish (Accession nos: EU862328, EU862329, EU862330, EU862331, EU862332, EU862333, EU862334) and IPN virus was present in all of the fish. The dominating bacteria were Vibrio splendidus-like. The mortality stopped one week before the start of the experiment. However, the fish were still positive for IPN virus at the time of challenge, i.e. they were carriers of the virus ( $\mathrm{Ct}$ values above 30). The fish remained positive for IPN virus throughout the experimental period and a few fish were also positive for Vibrio spp and Alivibrio spp. All fish tested before the start of the experiment were negative for VHS virus.

The mortalities in the different groups varied from $2.9 \%$ in the bath control group, BK $(\mathrm{N}=68)$, and up 
Table 2 Pairwise percent amino acid identities of FA28.11.07 proteins with protein sequences in other VHSV isolates.

\begin{tabular}{|c|c|c|c|c|c|c|c|c|c|}
\hline \multirow[b]{2}{*}{ Isolate code } & \multirow[b]{2}{*}{ Country/origin } & \multirow[b]{2}{*}{ Genotype } & \multicolumn{6}{|c|}{$\%$ Amino acid identity $^{a}$} & \multirow[b]{2}{*}{ Accession no. ${ }^{b}$} \\
\hline & & & $\mathbf{N}$ & $\mathbf{P}$ & M & G & NV & $\mathbf{L}$ & \\
\hline DK- Hededam & Denmark & । & 92.8 & 96.8 & 94.5 & 96.4 & 84.4 & 97.7 & Z93412 \\
\hline DE- Fil3 & Germany & $1-\mathrm{a}$ & 93.1 & 96.4 & 94.0 & 96.3 & 81.1 & 97.7 & NC_000855 \\
\hline FR-14-58 & France & $1-\mathrm{a}$ & 93.6 & 95.9 & 94.0 & 96.3 & 84.4 & 97.6 & AF143863 \\
\hline FR-07-71 & France & $1-\mathrm{a}$ & 92.6 & 94.1 & 94.5 & 95.3 & 82.8 & $83.8^{c}$ & AJ233396 \\
\hline FR-07-71 & France & $1-\mathrm{a}$ & - & - & - & - & - & $75.9^{c}$ & AJ009814 \\
\hline UK-96-43 & England & $\mathrm{I}-\mathrm{b}$ & 93.1 & 95.5 & 95.0 & 96.3 & 84.4 & 97.6 & AF143862 \\
\hline DK-M.rhabdo & Baltic Sea & $1-b$ & 93.6 & 95.5 & 94.5 & 97.0 & 90.2 & 98.6 & Z93414 \\
\hline DK-2835 & Denmark & I- $C$ & - & - & - & 95.9 & - & - & AY546585 \\
\hline FI-ka66 & Gulf of Bothnia & $1-d$ & - & - & - & 96.6 & - & - & AY546614 \\
\hline DK-1p52 & Baltic Sea & $\|$ & - & - & - & 94.3 & 70.5 & - & AY546576/DQ159194 \\
\hline DK-1p53 & Baltic Sea & $\|$ & - & - & - & 94.1 & 70.0 & - & AY546577/DQ159195 \\
\hline UK-860/94 & Scotland & III & - & - & - & 97.4 & 92.6 & - & AY546628/DQ159203 \\
\hline UK-H17/2/95 & North Sea & III & - & - & - & 99.2 & 96.7 & - & AY546629/DQ159202 \\
\hline DK-4p168 & Skagerrak & III & - & - & - & 99.8 & - & - & AY546582 \\
\hline UK-MLA98/6PT11 & North Sea & III & - & - & - & 99.4 & - & - & AY546632 \\
\hline DK-4p101 & North Sea & III & - & - & - & 97.6 & - & - & AY546581 \\
\hline UK-H17/5/93 & North Sea & III & - & - & - & 99.2 & - & - & AY546630 \\
\hline JF00Ehi1 & Japan & IV- a & 92.3 & 93.7 & 93.0 & 92.7 & 70.5 & 96.4 & AB490792 \\
\hline MI03GL & USA & $I V-b$ & 92.1 & - & - & 94.1 & - & - & DQ427105/DQ401193 \\
\hline
\end{tabular}

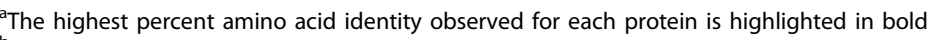

${ }^{b}$ Accession numbers are listed for complete genomes when available, and for the individual nucleotide sequences when not

${ }^{\mathrm{C}} \mathrm{Gaps}$ in the alignment

48.4\% in the i.p. challenged group, $\mathrm{V}(\mathrm{N}=31)$ (Figure $5)$. The mortality in the bath challenged group (BV, $\mathrm{N}=$ 68) was $44.1 \%$ while the mortality among the co-habitants ( $K V, N=30$ ) was $30 \%$. The total mortality in the tank challenged by homogenate from rainbow trout (group $\mathrm{H}, \mathrm{N}=61$ ) was $41 \%$. The group that was challenged with homogenate from VHS virus positive herring (group $\mathrm{CH}$ ) suffered $6.3 \%$ mortality.

Not all fish that died in the different groups were positive for presence of VHS virus. If the fish that were negative for presence of VHS virus are removed from the mortalities the pattern of mortality remains, however, more or less the same (Figure 6). The mortalities associated with presence of VHS virus in the $\mathrm{V}$ and BV were $41.9 \%$ and $44.1 \%$, respectively. None of the fish that died in the control group, $\mathrm{BK}$, or the $\mathrm{CH}$ group were positive for VHS virus. We were not able to identify any other pathogens that could explain the mortalities of the fish that were negative for presence of VHS virus.

None of the fish in groups $\mathrm{V}(\mathrm{N}=11)$ and $\mathrm{KV}(\mathrm{N}=$ 16) were positive for VHS virus at the termination of the experiment 53 days post challenge, while 2 and 3 fish out of 33 and 37 fish examined were positive in groups $\mathrm{BV}$ and $\mathrm{H}$, respectively. These five fish were carriers of VHS virus (ct values $>35$ ) and did not show any signs of disease. The virus was present in kidney, heart and spleen tissues, while the brain from one fish only was positive. Of the 97 fish sampled at the termination of the experiment 53 days post challenge $5.2 \%$ were carriers of the VHS virus.

Table 3 Amino acid residues that may play a role in the determination of virulence [19] when challenging rainbow trout.

\begin{tabular}{lcccccccccc}
\hline & \multicolumn{3}{c}{$\mathbf{N}$} & & & $\mathbf{P}$ & & $\mathbf{G}$ & \multicolumn{1}{c}{ L } \\
\hline Position & 82 & 83 & 371 & 392 & 39 & 41 & 78 & 506 & 1012 & 1465 \\
Amino acid & G-E & M-T & R-L & E-G & P-T & E-G & L-F & M-T & I-F & I-L \\
FA281107 & E & A & K & E & T & G & F & M & F & L \\
Other GIII & - & - & - & - & - & - & - & MN & - & - \\
\hline
\end{tabular}

The virulent strains are, Hededam and FR-14-58, are isolated from rainbow trout, while the avirulent strains, UK-96-43 and DK-M.rhabdo, are from herring and cod. Position = the position of the amino acid residues within the respective proteins. The first amino acid in each column was conserved among avirulent strains and the latter among virulent strains. The VHS virus isolate (FA28.11.09) from rainbow trout in Norway share 2 and 6 amino acids with the avirulent and virulent strains, respectively. No information is available about the $\mathrm{N}, \mathrm{P}$ and $\mathrm{L}$ proteins sequences from other genotype III isolates. 
Table 4 Amino acid residues in the $G$ protein that may play a role in the determination of virulence [22].

\begin{tabular}{lccccccc}
\hline \multicolumn{7}{c}{ G protein residues } \\
\hline & 118 & 135 & 139 & 140 & 161 & 431 & 433 \\
FR-07-71 & $\mathrm{Q}$ & $\mathrm{T}$ & $\mathrm{S}$ & $\mathrm{K}$ & $\mathrm{K}$ & $\mathrm{L}$ & I \\
FR-07-71 mutants & & & I/N & $\mathrm{R}$ & $\mathrm{R}$ & & $\mathrm{T}$ \\
Tr25 & $\mathrm{R}$ & $\mathrm{I}$ & $\mathrm{R}$ & $\mathrm{K}$ & $\mathrm{K}$ & $\mathrm{P}$ & $\mathrm{I}$ \\
Tr25 mutants & & & $\mathrm{N}$ & $\mathrm{N} / \mathrm{E}$ & & & \\
FA281109 & $\mathrm{Q}$ & $\mathrm{A}$ & $\mathrm{S}$ & $\mathrm{K}$ & $\mathrm{K}$ & $\mathrm{L}$ & I \\
Other GIII isolates & $\mathrm{Q}$ & $\mathrm{A} / \mathrm{T}$ & $\mathrm{S}$ & $\mathrm{K}$ & $\mathrm{K}$ & $\mathrm{L}$ & I
\end{tabular}

The FR-07-71 VHS virus isolate is highly virulent, while the mutant (07-71 mutant), Tr25 (an attenuated laboratory variant of FR-07-71), and Tr25 mutants have a low virulence. The VHS virus isolate (FA28.11.09) from rainbow trout in Norway share six out of seven amino acids with the virulent FR-07-71 strain.

The amount of VHS virus template in the kidney and brain of fish in the two challenge groups $\mathrm{V}$ and BV have been quantified using the elongation factor alpha as a standard. The kidney tissue from 13 individuals in group $\mathrm{V}$ was positive for presence of VHS virus template while only 10 individuals had positive brain tissue (CNS). In the BV group 28 and 27 individuals had positive kidney and CNS, respectively. Only one fish was found to be positive for VHS virus 20 days after injection of the virus (group V), while in the bath challenged group nine fish were positive. An individual sampled 12 days after challenge in group $\mathrm{V}$ had the highest expression of VHS virus genome/mRNA. This expression was 6.7 million times higher compared to the lowest expression (sampled 9 days post challenge) of these templates in positive kidney tissue. The individual, in the $\mathrm{V}$ group, with the highest expression of VHS virus template in the CNS was sampled 7 days post challenge. None of the fish in this group had positive CNS after 18 days post challenge. In the bath challenged group, BV, the highest expression of VHS virus templates in kidney tissue was found 11 days post challenge while the highest expression in the CNS was seen 42 days post challenge. The latter specimen had negative kidney tissue. Of the nine fish that were positive after day 20 post challenge five had positive kidneys and 8 had positive CNS.

VHS viruses were isolated from all challenged groups except the control group and the $\mathrm{CH}$ group. Partial sequences of the genome showed that the reisolated viruses were identical to the FA28.11.07 isolate (Accession no: BV group: FJ362510, FJ362511, H group: FJ362512, FJ362513, KV group: FJ362514, V group: FJ362515).

\section{Pathology}

The weight and length of the fish in the different groups at the termination of the challenge is given in table 5 . In all groups, including the control group (BK), some rainbow trout showed loss of scales and skin ulcers. In the two groups that were bath challenged (groups BV and $\mathrm{H})$ a few fish had haemorrhages on the viscera (figure 7A). A few fish in all VHS virus challenged groups, V, $\mathrm{KV}, \mathrm{H}$ and $\mathrm{BV}$, showed corkscrewing and had eye and somatic muscle bleedings (figure 7B), pale gills, slight epicarditis and some necrosis of heart myofibers in the ventricle. The most pronounced changes were seen in the kidneys which were slightly swollen with marked necrosis, haemorrhages and loss of haematopoietic cells (Figure 7C). Only minor changes were seen in the liver of strongly positive fish (Figure 7D).

The mean haematocrit values from moribund fish positive for VHS virus in groups $\mathrm{V}, \mathrm{KV}$ and $\mathrm{H}$ were about 23.0 and for those in group BV it was 12.5. In the control group $\mathrm{BK}$ and the challenged group $\mathrm{CH}$ the mean haematocrit values were about 55.0 in fish sampled before day 25 after challenge, while at the termination of the experiment the values were $58.1(\mathrm{~N}=$ $29)$ and $62.2(\mathrm{~N}=23)$, respectively. One moribund fish in group BK, collected 32 days after start of the experiment, had a haematocrit value = eight. The haematocrit values in all groups at the termination of the experiment are presented in table 5 .

\section{Discussion}

\section{Genome}

The complete genome of VHS virus isolates belonging to genotypes I $[19,20]$ and IV (accession no: AB490792) have already been published and this study presents the first complete sequence of the coding region of a genotype III isolate (FA28.11.07). Like all other members of the genus Novirhabdovirus the VHS virus genotype III has the same gene arrangement and similar intergenic regions (ITRs) with polyadenylation signals and transcription initiation sites [19,20,23-25]. There is little variation in the length of the ITRs within the VHS virus species, and the conserved motifs (A, B, C and D) in the $\mathrm{L}$ protein [cf [20]] are the same for all VHS viruses sequenced. The ATP binding site in FA28.11.07 is consistent with the consensus sequence for ATP binding sites found in a number of protein kinases and in other negative sense RNA virus polymerases [21].

The distribution of VHS virus genotype III in the North Sea and the North Atlantic ocean has been well documented [13,26-28]. Species like Atlantic Herring (C. herrengus),Norway pout (T. esmarkii) and predators of these species, like cod (G. morhua) and haddock ( $M$. aeglefinus) could carry the virus close to aquaculture facilities. Virulence factors for the VHS virus have not been identified, but it has been shown that the genetic difference between virulent freshwater strains and avirulent marine strains can be very small [19]. VHS virus, like all reproducing units (based on RNA or DNA), consists of populations individuals (virions) that 


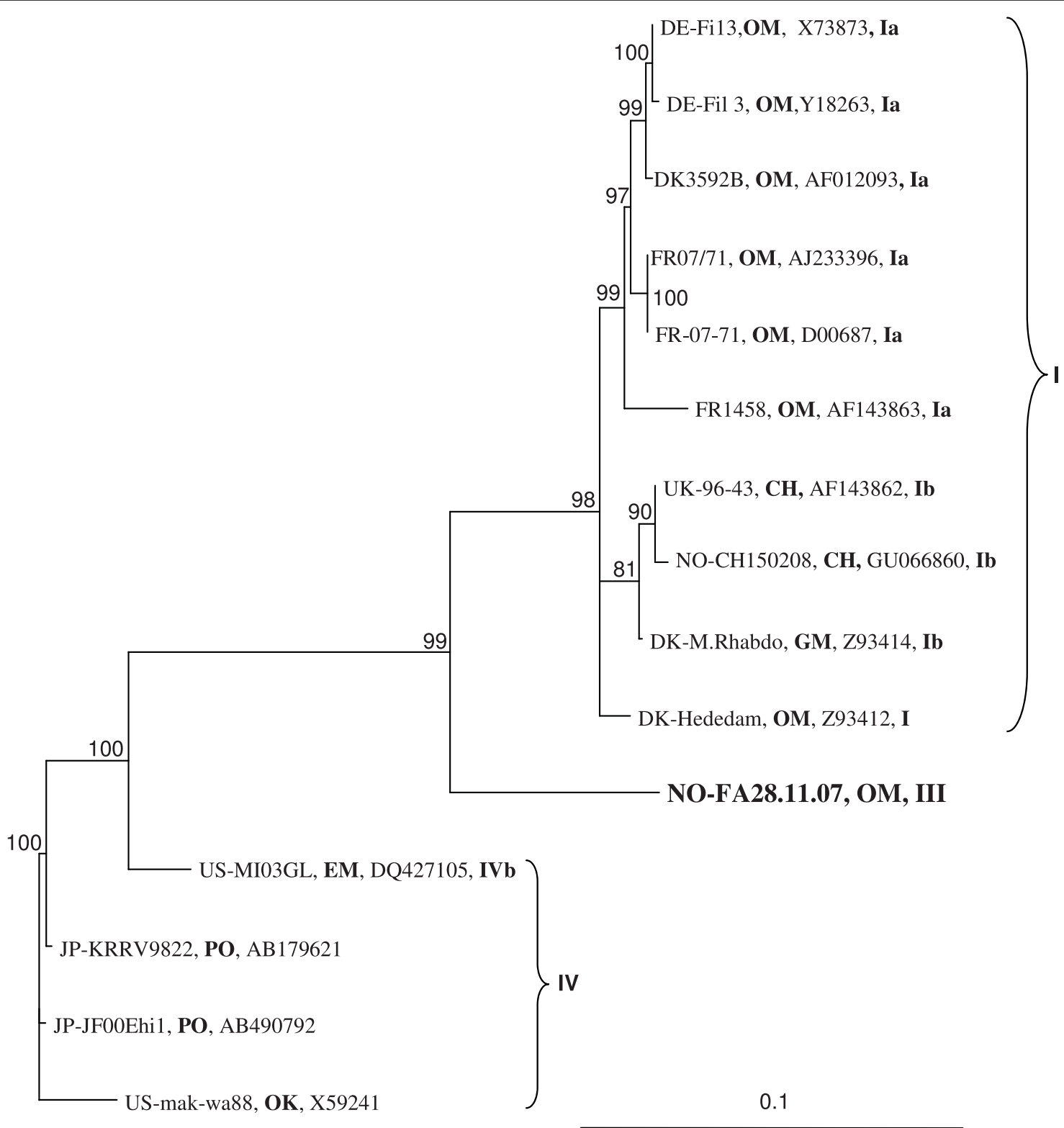

Figure 3 The phylogenetic relationship of the VHS virus isolate (FA28.11.07) from rainbow trout collected in Norway in 2007 based on the complete sequences of the $\mathbf{N}$ protein ORF. A VHS virus form herring ( $\mathrm{CH} 18.03 .08)$ collected in the same area is also included.

Phylogram resulting from maximum-likelihood analysis in TREE-PUZZLE (quartet-puzzling). The scale bars shows the number of substitutions as a proportion of branch lengths. $\mathbf{C H}=$ Clupea harengus, $\mathbf{E M}=$ Esox masquinongy, $\mathbf{G M}=$ Gadus morhua, $\mathbf{O K}=$ Oncorhynchus kisutch, $\mathbf{O M}=$ O.mykiss.

vary in genotypes and appear in a mutation-selection balance. This natural variation will increase as a result of mutation and mutation rates may be high in RNA viruses. The mutation rate of VHS virus genotype III in natural populations is, however, not known. The different variants constituting a virus population consist of highly related virions that may have different phenotypical properties [29]. Hence, when a farmed population of rainbow trout is exposed to a population of marine VHS viruses the variant best adapted to this new host will dominate and may cause disease [3]. The virus may also mutate after it has infected rainbow trout, but there can be no replication followed by mutations unless the virus is able to infect and multiply in rainbow trout. Hence, the VHS virus detected in the rainbow trout farm in Storfjord must have been "pre-adapted" to this fish species, while the VHS virus from herring (CH15.02.08), collected in the outlet of Storfjorden, was not able to establish an infection in rainbow trout. 


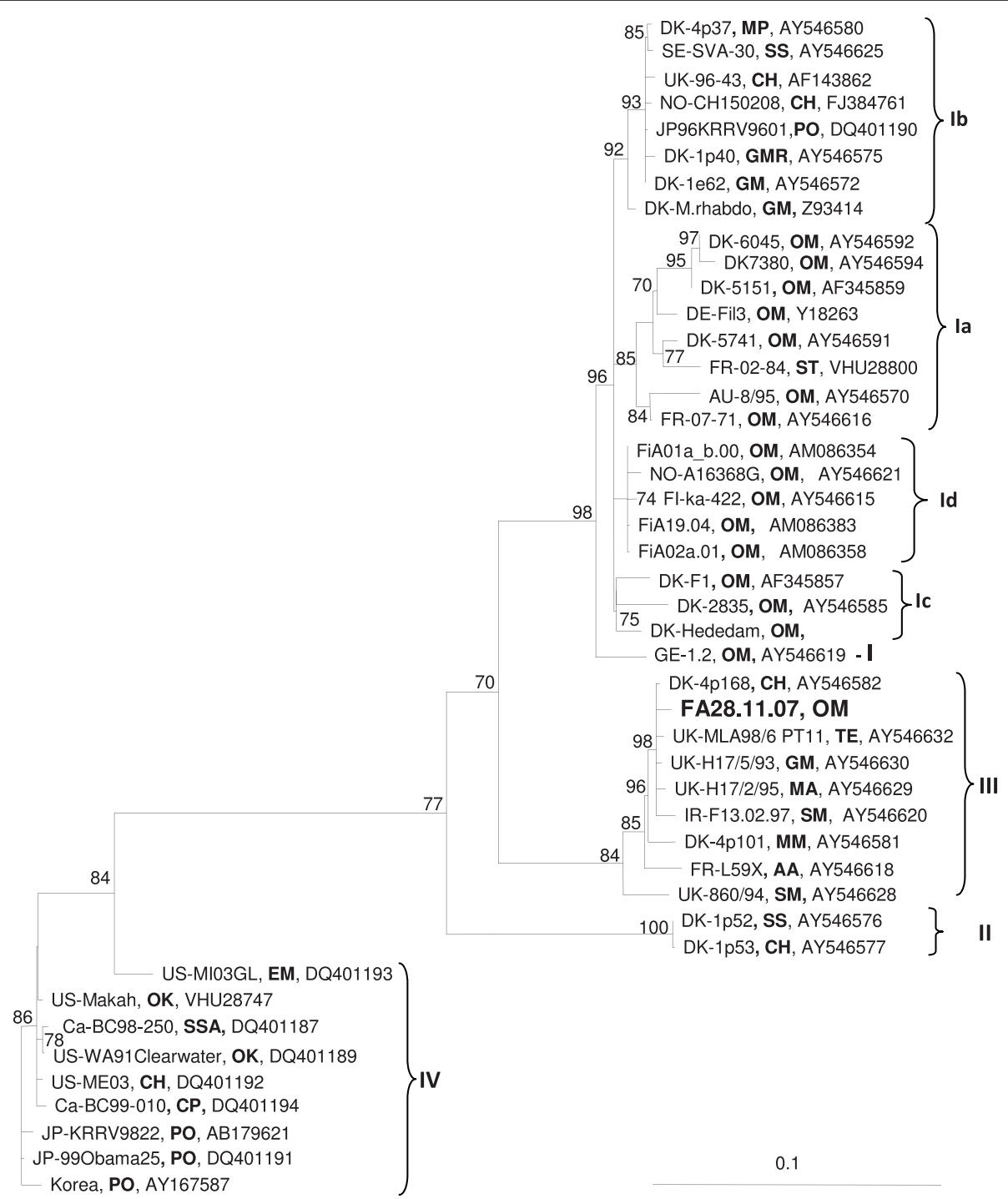

Figure 4 The phylogenetic relationship of the VHS virus isolate (FA28.11.07) from rainbow trout collected in Norway in 2007 based on the complete sequences of the G protein ORF. FJ384761 and AY546621 are VHS viruses from Norway. Phylogram resulting from maximum-likelihood analysis in TREE-PUZZLE (quartet-puzzling steps). The scale bars shows the number of substitutions as a proportion of branch lengths. $\mathbf{A A}=$ Anguilla anguilla $\mathbf{C H}=$ Clupea harengus, $\mathbf{C P}=$ Clupea pallasii, $\mathbf{M P}=$ Micromesistius poutassou, $\mathbf{E M}=$ Esox masquinongy, $\mathbf{G M}$ = Gadus morhua, GMR = Gaidropsaurus mediterraneus, $\mathbf{M A}=$ Melanogrammus aeglefinus, $\mathbf{M M}=$ Merlangius merlangus, $\mathbf{O K}=$ Oncorhynchus kisutch, $\mathbf{O M}=$ O.mykiss, $\mathbf{S M}=$ Scophthalmus maximus, $\mathbf{P O}=$ Paralichthys olivaceus, $\mathbf{S S}=$ Sprattus sprattus, $\mathbf{S S A}=$ Salmo salar, $\mathbf{S T}=$ Salmo trutta .

\section{Challenge experiment}

The fish used in the challenge study suffered a low mortality the first two weeks after arrival, but the mortality ceased one week prior to the challenge. A single cause of these mortalities was not identified, but several factors could have played a role. The fish were taken from a fresh water site, and put directly in full seawater and this stressful event was probably the main cause for the mortalities. However, among the mortalities were fish positive for bacteria and IPN virus. These agents may have affected the mortality observed in the period before start of the challenge and during the experimental period. The IPN virus detected before challenge was also present in the fish throughout the experimental period, but at a low level (carrier state). IPN viruses are very common in the production of salmonids in Norway and it is not known if these virus infections may interfere with infections with VHS virus.

It has been shown in virulence studies of VHS viruses that the challenge method is important for the resulting mortality [12]. Using marine isolates of VHS virus they found that immersion did not cause any mortality while some of the same isolates caused mortality when injected. The mechanism behind this has been studied 


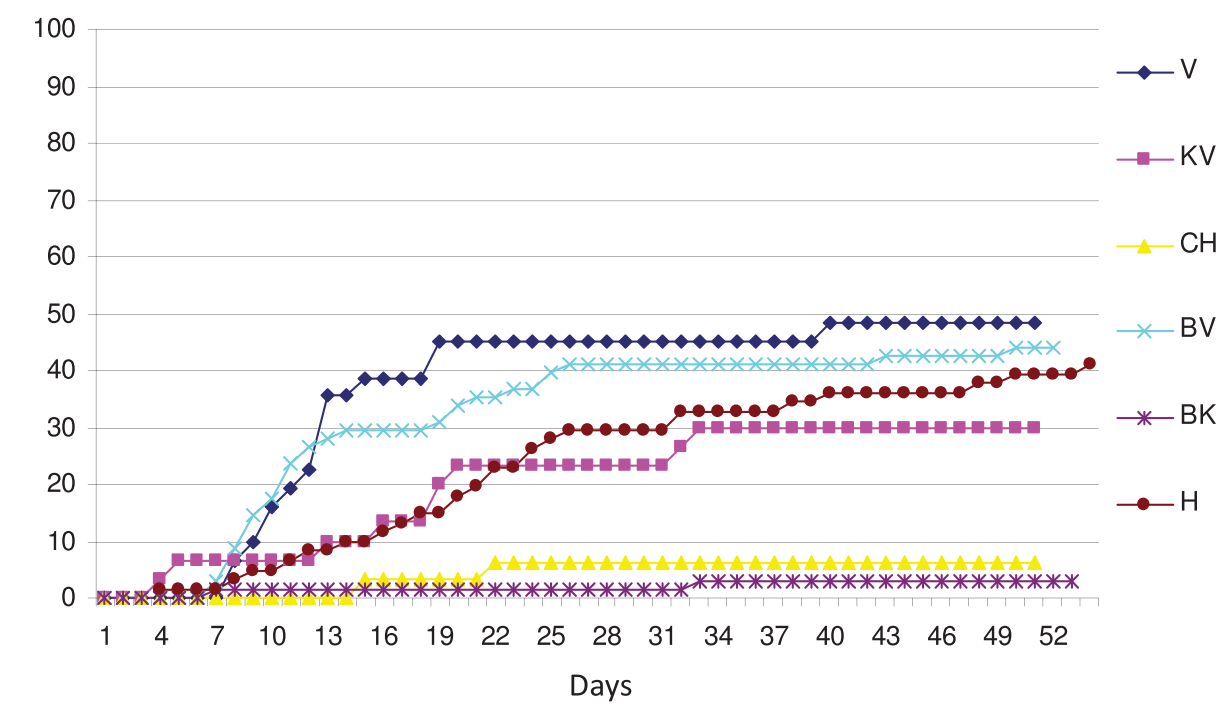

Figure 5 Percent mortality in the different groups during experimental period. $V=$ i.p. challenged rainbow trout, $O$. mykiss (isolate FA28.11.07), KV = co-habitants with the i.p. challenged O. mykiss (isolate FA28.11.07), BV = bath challenged O. mykiss (isolate FA28.11.07), $\mathrm{H}=$ group bath challenged with homogenate from VHS virus positive $O$. mykiss, BK = control group for the two groups of bath challenged 0 . mykiss, and $\mathrm{CH}=$ rainbow trout i.p. challenged with VHS virus from herring $(\mathrm{CH} 18.03 .08)$.

by Brudeseth et al [30], who found inefficiency at infecting rainbow trout to correlate with a weak ability of the virus to translocate over polarized, primary GEC cultures and a low level of in vitro infectivity of VHS virus isolates in primary cell cultures. The present study shows that rainbow trout in full sea water suffers a moderate mortality (about $40 \%$ ) after exposure to the marine VHS virus genotype III isolate, FA28.11. 07, irrespective of challenge method (immersion or injection). However, the mortalities obtained in this study are relatively high (regardless of infection route), compared to previous studies where rainbow trout has been challenged with genotype III isolates of VHS virus $[12,31]$, but much lower than observed by Dale et al [9]. In the latter study [9] 10.1 gram rainbow trout fingerlings were challenged, using a VHS virus isolate from

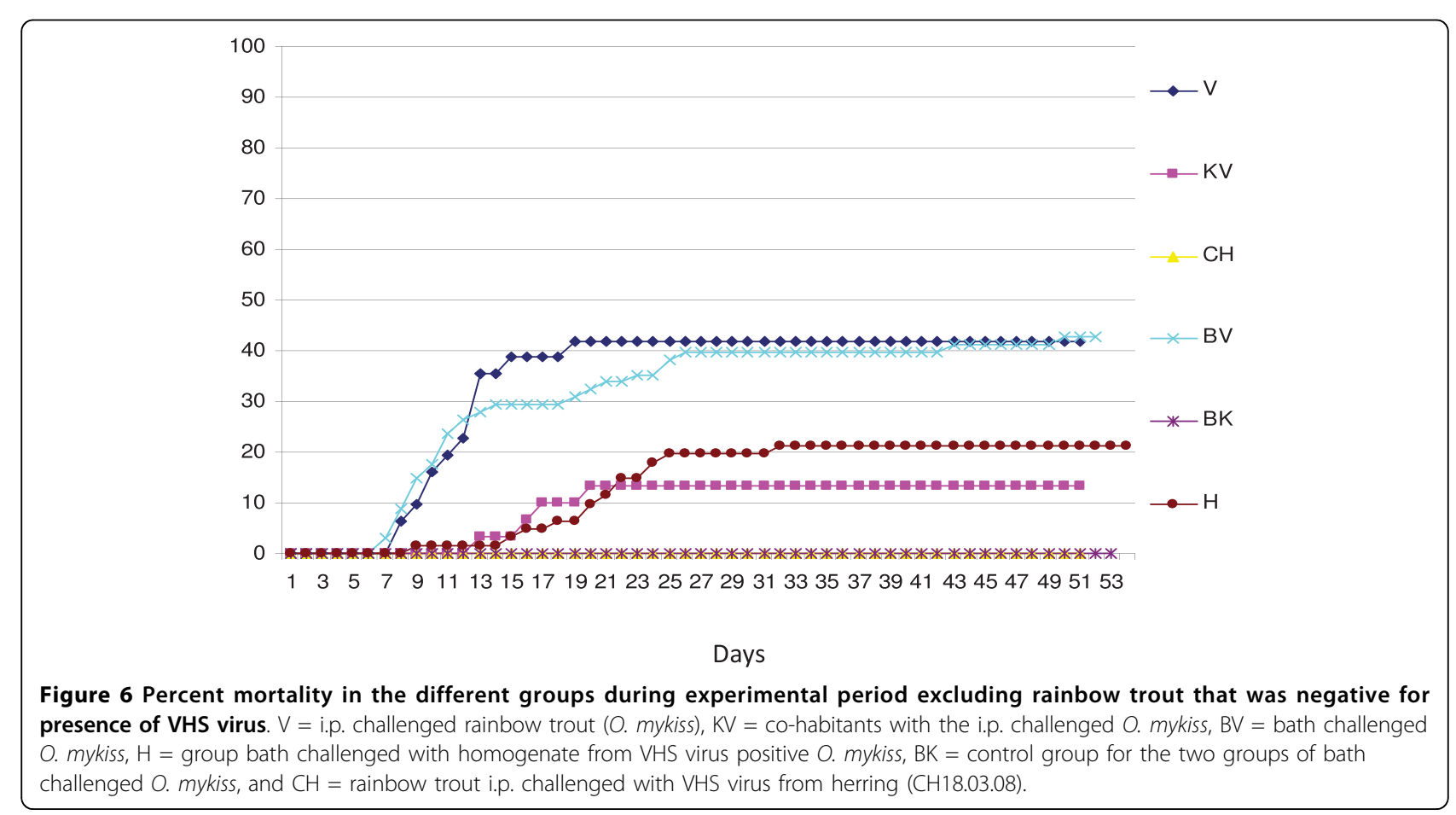



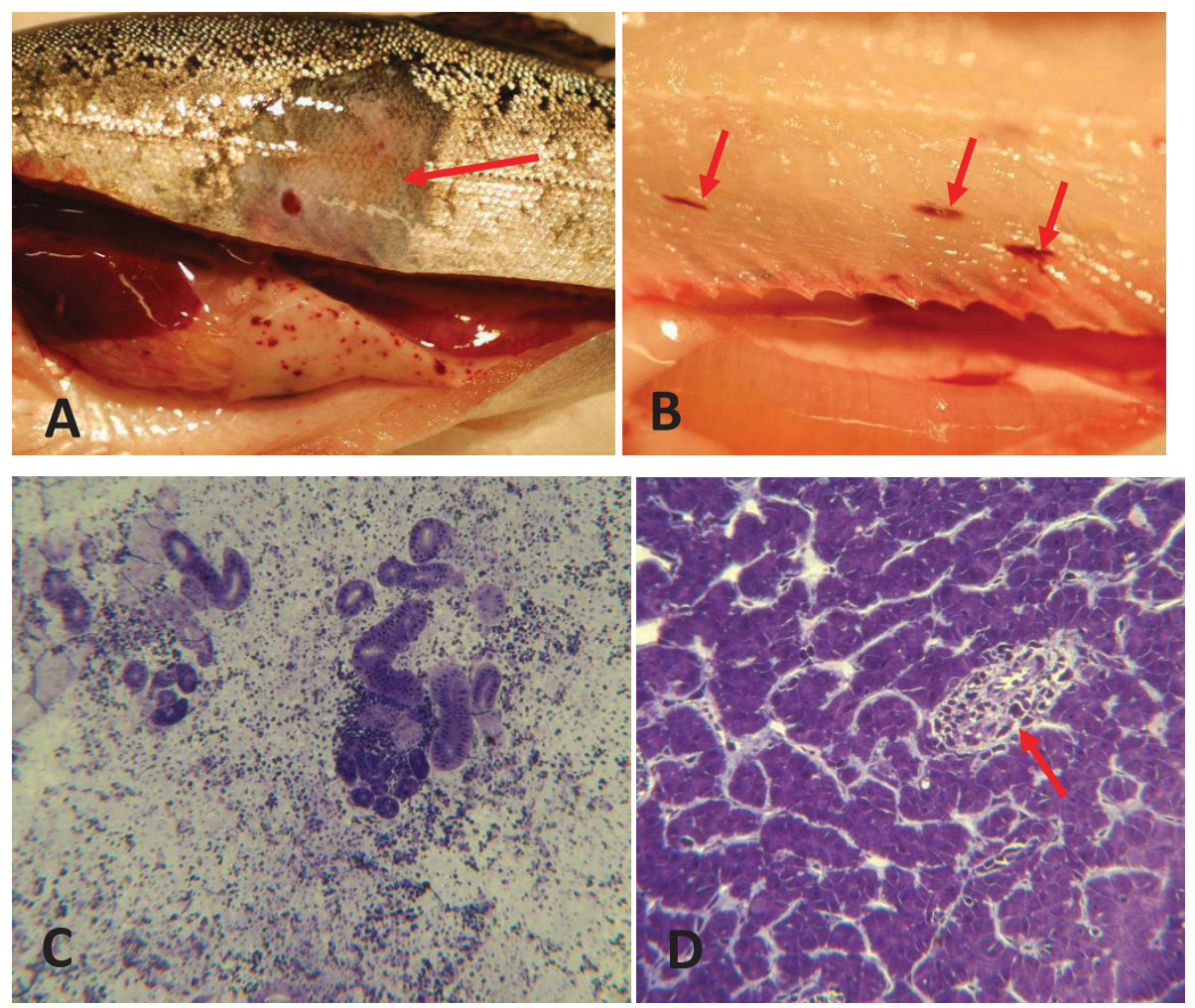

Figure 7 Pathology. A) Rainbow trout from the co-habitation group (KV) collected 12 days after challenge. Note the loss of scales and epidermis (arrow) and haemorrhages on the vicera. This individual was positive (kidney; $\mathrm{Ct}=26$ ) for presence of VHS virus. B) Rainbow trout from the bath challenged group (BV) collected 7 days after challenge showing haemorrhages (arrows) in the somatic muscle (kidney, VHSV Ct $=$ 27). C) Loss of haematopoietic cells and massive haemorrhages in the kidney of a rainbow trout (KV group) collected 18 days after challenge (kidney; VHSV Ct $=36$, spleen; VHSV Ct $=28$ ), D) Accumulation of inflammatory cells (arrow) surrounding a blood sinus in the liver of rainbow trout (group BV) collected 19 days after challenge (kidney, VHSV Ct $=24$ ).

the same farm as the isolate used in this study, and the resulting mortalities were $100 \%$ and $70 \%$ after intraperitoneal injection and immersion, respectively. This is very different from the moderate mortality seen in this study where the mortality in the bath challenged group (BV) was slightly higher than in the ip challenged group (V). In the present study the conditions were full seawater and fish with a mean weight of 47.4 grams (at the start of the experiment), hence, the conditions were as close as possible to that in the marine farm where the

Table 5 Mean weight, length, and Hct of the experimental fish in the different groups at the termination of the experiment 53 days post challenge.

\begin{tabular}{ccccc}
\hline Group & N & Weight & Length & Hct \\
\hline V & 11 & 115.1 & 20.7 & 61.3 \\
KV & 16 & 133.2 & 21.6 & 66.9 \\
H & 35 & 111.9 & 20.9 & 54.3 \\
BV & 33 & 108.8 & 20.6 & 56.8 \\
BK & 29 & 112.4 & 20.9 & 58.1 \\
CH & 23 & 122.7 & 21.7 & 62.2 \\
\hline
\end{tabular}

outbreak occurred and the virus was isolated. In our opinion the use of rainbow trout fingerlings in fresh water [9] is not a suitable system for challenge experiments using marine VHS virus isolates with the aim to obtain knowledge about susceptibility and virulence in marine farms. The use of fingerlings was originally implemented for the study of VHS virus genotype Ia which normally affects rainbow trout fingerlings in freshwater production in Europe. The genotype Ib isolate $(\mathrm{CH} 15.02 .08)$ from herring did not result in any mortality and the virus did not replicate in the rainbow trout.

The fish in the $\mathrm{V}$ and BV group in this experiment, were challenged with a high dose (i.p. injection $\mathrm{TCID}_{50}$ $=0.5 \times 10^{8} \mathrm{TCID}_{50} /$ fish and bath $\mathrm{TCID}_{50}=0.8 \times 10^{8}$ $\mathrm{TCID}_{50} / \mathrm{ml}$ ), which is exceedingly higher than what has been reported by other studies infecting rainbow trout with marine genotypes $[9,12,31,32]$ and challenge experiments of other species [13-16,33-35]. This high dose may have contributed to the mortality seen in this study, however, the fish in the $\mathrm{H}$ group had approximately the same cumulative mortality as the BV group, 
and this fish was bath challenged in tissue homogenate with a low amount of VHS virus. Hence, the VHS virus isolate, FA28.11.07, seems to be more virulent for rainbow trout compared to other VHS viruses isolated from marine fish including the isolate $(\mathrm{CH} 15.02 .08)$ from herring collected in the same area. It remains to be shown if this isolate (FA28.11.07) is present in wild fish in western Norway or if the virus has adapted to farmed rainbow trout with a resulting increased virulence.

It has been reported that VHS survivors could become lifetime carriers of the virus, and that they may function as reservoirs for further transmission of the virus [36]. In this study the number of VHS virus positive fish was few at the termination of the experiment. At day 53 only 5 out of a total of 96 survivors from all groups, were positive for VHS virus. These five fishes all had high Ct-values suggesting that a low amount of VHS virus was present in the tissues. These fish that could possibly become carriers, all belonged to the two groups that were bath challenged. The groups challenged by i.p. injection with cultured virus and their cohabitants seemed to rid themselves of the virus. The fate of the possible carrier fish was not determined. However, there could be three possible outcomes; I) the fish will eventually develop disease and die, II) they may continue as carriers or III) they may rid themselves of the virus. The statement that VHS virus infections may lead to lifelong latent infections in surviving fish, which later may infect new hosts [36], must be considered in relation to other studies that report limited viral recovery in surviving fish after challenge experiments with VHS virus $[15,37]$. Real time RT-PCR analysis of 60 rainbow trout from the affected farm in Storfjorden, Norway, three months after the outbreak of disease, failed to detect VHS virus in kidney and CNS of the fish sampled (Vidar Aspehaug, pers com). Hence, it is a possibility that surviving rainbow trout, after a challenge with the VHS virus genotype III isolate FA28.11.07, are able rid themselves of this virus. To confirm this it will be necessary to follow the fish over a longer period.

\section{Virulence}

According to Gaudin et al [22] a single mutation at position $139(\mathrm{~S}-\mathrm{I} / \mathrm{N})$ in the $\mathrm{G}$ protein was enough to lower the virulence of mutant isolates of genotype I, and this was further decreased by an additional mutation at positions $140(\mathrm{~K}-\mathrm{R})$ and $433(\mathrm{I}-\mathrm{T})$. A third mutation at position $161(\mathrm{~K}-\mathrm{R})$ resulted in the most attenuated phenotype. Mutations at positions $118(\mathrm{Q}-\mathrm{R}), 135$ (T I) and $431(\mathrm{~L}-\mathrm{P})$ also seem to lower the virulence of type I VHS virus isolates, and Gaudin et al [22] concluded that simultaneous mutations in two distant regions of the glycoprotein (region I aa 135 - 161 and region II aa 431 - 433) could give maximal attenuation of virulence. The FA28.11.07 isolate, presented in this study, which has an identical nucleotide sequence with another isolate from this farm [9], shares all but one amino acid (position 135) with the highly virulent FR07-71 isolate. At this position the FA28.11.07 isolate has an alanine instead of the threonine found in isolate FR07-71. However, FA28.11.07 shares the same amino acids in these positions with other marine genotype III isolates shown to be of low virulence $[12,13]$. Hence, there is no support for claiming that substitutions at these positions affect the virulence of genotype III isolates.

The genotype III isolate UK-860/94, from farmed turbot in Scotland, showed increased virulence for rainbow trout after five in vivo passages in rainbow trout [38]. They were not able to detect any mutations in the sequence of the G-protein gene, but suggested that other genes might have been responsible for the observed increase in virulence [38]. If they are correct there is a possibility that a marine genotype III virus could have been recently transmitted from a marine carrier fish to rainbow trout in aquaculture and, in a short time, evolved increased virulence. It has been suggested that 10 amino acid positions in four proteins $(\mathrm{N}, \mathrm{P}, \mathrm{G}$ and L), may be virulence markers [19]. The FA28.11.07 isolate shares the majority (six) of the amino acids with the virulent fresh water strains of genotype I isolates and only two amino acids with the avirulent marine strains. Hence, it can be concluded that the genotype III VHS virus isolate FA28.11.07 shares many of the amino acid residues with that of highly virulent fresh water genotype I isolates. However, no information is available about these amino acid positions in the low virulent strains within genotype III. Considering the relatively high mortality obtained after bath challenge in the present study, compared to similar experiments with other marine genotype III VHS viruses, the factors influencing virulence have yet to be identified.

\section{Conclusions}

Based on analyses of the nucleotide sequences of the complete ORF of the $\mathrm{N}$ and $\mathrm{G}$ proteins it can be concluded that the VHS virus isolate FA28.11.07 is a new, distinct, isolate belonging to genotype III, and being moderately virulent to rainbow trout [cf [3-5,11,32,39]]. Only future research can show if this VHS virus isolate from rainbow trout in Storfjorden also exits in natural populations of marine fish in the fjord or if the isolate represents a new adaptation to rainbow trout.

\section{Materials and methods}

In November 2007 a viral haemorrhagic septicaemia virus (VHSV), genotype III (Accession nos: EU336985, EU481506), was isolated from rainbow trout (Oncorhychus mykiss) suffering mortality in a marine farm in 
Storfjorden at the northern west coast of Norway [10]. The VHS virus isolate has been named FA28.11.07, and the third passage of this isolate was used to challenge rainbow trout in full sea water. Nearly identical VHS virus isolates were found in two neighboring rainbow trout farms (isolate FA28.02.08S, accession nos: GU121099, GU121100 and isolate FA28.02.08V, Accession nos: GU121101, GU121102), and in July 2008 this virus was also found in a more distant farm in the same fjord. All farms are owned by the same company.

In addition to VHS virus type III, the rainbow trout in the first farm were infected by Candidatus Piscichlamydia salmonis, an unidentified chlamydia-like species, Flavobacterium psychrophilum, and a new species of microsporidia, Paranucleospora theridion. It is not known to what extent these pathogens may have contributed to the mortality or to what extent the mortality was caused by the VHS virus. However, after screening with real time RT PCR (primers and probe described below), only 2 out of 30 moribund rainbow trout were found to be positive for presence of VHS virus on the collection date 28 November 2007. The number of VHS virus positive fish increased to $50 \%$ in the middle of December 2007, while it was not possible to detect the virus in kidney and brain tissues from fish $(\mathrm{N}=60)$ sampled in March 2008 (V. Aspehaug, pers. com.)

A VHS virus isolate was also obtained from herring (Clupea harengus) collected at the outlet of Storfjorden, but this isolate $(\mathrm{CH} 18.03 .08)$ belonged to genogroup $\mathrm{Ib}$ (Accession nos: FJ384761, GU066860).

\section{Challenge experiment}

Rainbow trout, with a mean weight and length of 47.4 gram and $15.7 \mathrm{~cm}$, were taken into the research facility, Industrilaboratoriet, at the University of Bergen in January 2008. The fish came from a fresh water site in western Norway and were put directly in full sea water $(34 \% 0)$. A low mortality was registered during the first two weeks after arrival and some of the fish had skin ulcers. Bacteria, Vibrio spp were isolated from a few of the moribund fish during the first two weeks after arrival. However, the major loss of fish was probably due to poor smoltification, and the mortality stopped a week before the fish were used in the challenge experiment. A subsample of fish $(\mathrm{N}=40)$ were checked for presence of VHS virus and IPN virus, using real time RT PCR assays (see below), before the start of the experiment. None of the fish that died during the acclimatization period were positive for VHS virus, but they were all carriers of the IPN virus and a few were positive for different bacteria (Vibrio spp. and Moritella viscosa). The fish were kept in 5 tanks $\left(0.15 \mathrm{~m}^{3}\right)$ with running sea water $(34 \%)$ at mean temperature of $10^{\circ} \mathrm{C}$.

The challenge experiment was designed to see if the VHS virus isolate, FA28.11.07, may cause mortality and if different challenge methods may influence mortality. The wild type VHS virus from herring $(\mathrm{CH} 15.02 .08)$ was used as a control.

\section{Tank 1}

This tank was used to test the effect of intraperitoneal injection (ip) of the VHS virus isolate FA28.11.07 and the effect of transmission from infected to non-infected rainbow trout (co-habitation effect). Rainbow trout, $\mathrm{N}=$ $31($ code $=V)$, were injected intraperitoneal (ip) with 0.2 $\mathrm{ml}$ of supernatant from cell culture with TCID50 of 1.0 $\times 10^{9} / \mathrm{ml}$, ie. giving a final challenge dose of TCID50 $=$ $1.1 \times 10^{6} /$ gram fish tissue (or TCID50 $=0.5 \times 10^{8} /$ fish) . In addition to the ip challenged fish 30 rainbow trout $($ code $=\mathrm{KV})$ were added as co-habitants. A total of 61 rainbow trout were kept in tank 1 .

\section{Tank 2}

This tank contained 68 rainbow trout $($ code $=\mathrm{BV})$ that were challenged by a bath consisting of $15 \mathrm{ml}$ of the VHS virus isolate FA28.11.07 $\left(\right.$ TCID50 $=1.0 \times 10^{9} \mathrm{VHS}$ virions $/ \mathrm{ml}$ ) in 20 liter sea water for 30 minutes, i.e. at a concentration of TCID50 $=0.8 \times 10^{6} / \mathrm{ml}$.

\section{Tank 3}

This tank contained 68 rainbow trout (code $=$ BK) that were bathed in $15 \mathrm{ml}$ cell culture media in 20 liter sea water for 30 minutes. This group constituted the control group for the bath challenged rainbow trout.

\section{Tank 4}

This tank was used to test if VHS virus from rainbow trout carriers could be transmitted by bath challenge. Rainbow trout, $\mathrm{N}=61$ (code $=\mathrm{H}$ ), were bathed for one hour in 20 liters of sea water added $45 \mathrm{ml}$ of sterile filtered homogenate $(0.2 \mu \mathrm{m})$ of gill and kidney tissues from rainbow trout that were asymptomatic carriers of VHS virus. It was not possible to culture the virus from this homogenate. The virus was only detected by real time RT PCR. The homogenate was obtained from carrier rainbow trout that came from the same marine farm as the VHS virus isolate FA28.11.07.

\section{Tank 5}

This tank was used to test the possible effect on rainbow trout of a wild type VHS virus detected in herring (CH18.03.08) from the outlet of Storfjorden. Homogenate made from brain and kidney tissue of the herring was intraperitoneal injected into rainbow trout, $\mathrm{N}=30$ $($ code $=\mathrm{CH})$. Each fish was injected with $0.2 \mathrm{ml}$ of sterile filtered homogenate $(0.2 \mu \mathrm{m})$.

\section{Sampling}

Dead and moribund fish were removed from the tanks two times a day, and weight and length were registered. All fish were examined for external and internal signs of disease. To rule out bacterial infections as a cause of mortality, bacterial samples were taken from a selection of dead/moribund fish and fish sampled randomly. Bacteria were isolated from kidney and grown 
on blood agar plates containing $1.5 \% \mathrm{NaCl}$ and incubated at $15^{\circ} \mathrm{C}$ for at least two weeks. When growth was observed on the agar plates the bacteria were identified by sequencing of the $16 \mathrm{~S}$ gene using a set of general prokaryotic primers targeting this gene (see below).

The following tissues were sampled from all dead/ moribund fish; gills, heart, kidney, spleen, and CNS. The tissues were stored at $-20^{\circ} \mathrm{C}$ before being used for reisolation of the VHS virus or RNA extraction. All dead/ moribund fish were tested for presence of VHS virus and IPN virus by real-time RT-PCR. To obtain information about tissue tropism the head-kidney, heart, spleen and CNS tissues were tested from 25 fish with respect to presence of VHS virus. Based on the results from the tissue tropism study the kidney and CNS from all fish in the different groups were tested for VHS virus, while only the kidneys were tested for presence of IPN virus. A blood sample, for measuring the haematocrit, was taken from all fish.

Several tissues (skin, gill, heart, kidney, spleen, gut and CNS) were sampled from a few individuals in each group and fixed in Karnovsky for examination of histopathology.

\section{Culturing VHS virus}

RTgill-W1 cells [40] were cultured in $15 \mathrm{~cm}^{2}$ tissue culture flasks (Nunc) at $20^{\circ} \mathrm{C}$ in Eagles Minimum Essential Medium (EMEM) (Sigma) supplemented with $10 \%$ Foetal Bovine Serum (FBS) (10\% v/v), L-glutamine (4 mM) and gentamicin $(50 \mu \mathrm{g} / \mathrm{ml})$. The cells were then subcultured for 7-10 days until the tissue flasks were covered with $60-80 \%$ confluent monolayer.

Supernatant containing VHS virus isolate FA28.11.08 (second passage) was diluted 1:100 in PBS and incubated for 1 hour at $15^{\circ} \mathrm{C}$ in cell culture flasks with the monolayer of RTgill-W1 cells. The inoculum was then removed and replaced by supplemented EMEM as described above, but with $1 \%$ FBS. The cells were incubated for five days until cytopathic effect (CPE) could be observed. RNA was extracted from infected cells and reverse transcribed into cDNA as previously described [41] and a real time RT PCR assay was used to test for presence of VHS virus.

\section{Virus titration}

RT-gill W-1 cells were seeded in a 96-well tray and allowed to form a monolayer. A 10-fold dilution series of the VHS virus isolate was made in $2 \%$ infection medium and added to the monolayers. To each well, $200 \mu \mathrm{l}$ of each dilution, ranging from $10^{1}$ to $10^{17}$, was added. Each dilution was used in four parallel wells. The 96well tray was incubated for 10 days, and $\mathrm{TCID}_{50}$ (The dilution in which $50 \%$ of the cells are dead) was determined by comparing with uninfected cells.

\section{Re-isolation of virus}

RTgill-W1 cells were also used for reisolation of VHS virus from the different fish groups challenged. Tissue homogenates were made from kidney or CNS tissues from selected fish (Codes: $\mathrm{V}, \mathrm{KV}, \mathrm{BV}, \mathrm{BK}, \mathrm{H}$ and $\mathrm{CH}$ ) in the different groups and sterile filtered $(0.2 \mu \mathrm{m})$ before inoculation on the cells. The cells were kept for three passages or until a CPE could be observed. Presence of VHS virus in cell cultures was confirmed by real time RT PCR and sequencing of the PCR products.

\section{Histopathology}

Tissues (skin, gills, heart, head-kidney, kidney, spleen, and brain) collected were fixed by immersion, at $6^{\circ} \mathrm{C}$, in a modified Karnovsky fixative where the distilled water was replaced by a Ringers solution. The fixative contained $4 \%$ sucrose. Before embedding in Historesin the tissues were dehydrated through graded series of ethanol as recommended by the manufacturer. Semi sections, $1.5 \mu \mathrm{m}$ thick, were cut on a Reichert-Jung 2050 microtome and stained in toluidine blue. 3 Before embedding in EMBED-812 (Electron Microscopy Sciences) the tissues were stained/post-fixed in $1 \% \mathrm{OsO}_{4}$. Ultrathin sections were cut on Reichert-Jung Ultracut E. The ultrathin sections $(30-40 \mathrm{~nm})$ were stained for 1.5 hours in $2 \%$ aqueous uranyl acetate solution and then stained with lead citrate.

\section{DNA/RNA extraction}

The extractions of RNA from tissues were performed as described by Devold et al. [41]. RNA-pellets were eluted in $100 \mu \mathrm{LEPC}$-water and stored at $-20^{\circ} \mathrm{C}$ until examination by real time RT-PCR.

cDNA synthesis was performed as follows; $5 \mu \mathrm{l}$ DEPCwater, $1 \mu \mathrm{l} \mathrm{pd}(\mathrm{N})_{6}$ (random hexamers) and $4 \mu \mathrm{l}$ RNA template, making a total of $10 \mu \mathrm{l}$, was incubated at $70^{\circ} \mathrm{C}$ for $5 \mathrm{~min}$. A RT-mix was made from $5 \mu \mathrm{l} 5 \times$ RT-buffer 5, 1,25 $\mu$ l DTT (200 mM DL-dithiothreitol), 2,5 $\mu 110$ mM dNTP, 0,5 $\mu \mathrm{l}$ RNasin, 0,15 $\mu \mathrm{l} \mathrm{MMLV}$ and 5,6 $\mu \mathrm{l}$ DEPC-water, making a total volume of $15 \mu \mathrm{l}$. This RTmix was added to the $10 \mu \mathrm{l}$ template/pd(N) ${ }_{6}$ mix making a total volume of $25 \mu \mathrm{l}$. This solution was incubated at $37^{\circ} \mathrm{C}$ for $60 \mathrm{~min}$ [41] after which the cDNA was stored at $-20^{\circ} \mathrm{C}$.

DNA was extracted from all isolated bacteria using the DNeasy DNA Tissue kit (Qiagen) following the manufactures description of protocol. Elution was performed twice in $50 \mu \mathrm{l} 10 \mathrm{mM}$ Tris- $\mathrm{HCl}, \mathrm{pH}=8.5$ to increase the overall DNA yield, and the DNA was stored at $-20^{\circ}$ C.

\section{PCR and sequencing}

The partial G gene (654 nucleotides) from VHS virus present in tissues of challenged rainbow trout and virus isolated from challenged fish in cell culture, was obtained by PCR using the cDNA synthesized as 
described above (accession nos: FJ362510, FJ362511, FJ362512, FJ362513, FJ362514, FJ362515). VG1 (5'-ATG GAA TGG AAC ACT TTT TTC-3') and VD3 (5'-TGT GAT CAT GGG TCC TGG TG-3') were used as PCR primers [42]. The nearly complete genome of the VHS virus isolate FA28.11.07 was obtained by using primers targeting the genome of other VHS virus belonging to genotypes I and IV (The primers can be obtained from the authors).

The partial 16S genes from isolated bacteria were obtained by the following primers; EUGB27F and EUGA1518R [43].

PCR products were run on electrophoresis gels for visualization and the products were purified using QIAquick PCR purification kit (Qiagen) as described by the manufacturer. Sequencing was then performed in both directions using ABI PRISM BigDye terminator chemistry (version 2) according to Applied biosystems (ABI). The PCR primers were used for sequencing.

\section{Real time RT-PCR}

In this experiment six real time RT-PCR assays were used (table 6). Primers and a probe able to detect both VHS virus genotype I and III were obtained by a modification of an assay developed by Mike Snow [44]. The assay targets a region of the nucleoprotein of VHS virus, ie. position 194 - 302 in the ORF of the $\mathrm{N}$ gene (Accession no: EU481506).

The internal control assay El-1A targets the Atlantic salmon cellular elongation factor [45]. The assays for detection of Paranucleospora theridion, Flavobacterium psychrophilum, Candidatus Piscichlamydia salmonis and the new chlamydia species, targeting the genes coding for the SSU, are presented in table 6.

Verso $^{\text {Tn }}$ 1-step QRT-PCR ROX Kit and Absolute ${ }^{\text {th }}$ QPCR ROX Mix were used for the real time RT-PCR assays. Analysis was performed in a ABI 7500 sequence detection system (Applied Biosystems). The reaction was $15 \mathrm{~min}$ at $50^{\circ} \mathrm{C}$ (Reverse Transcriptase step), $15 \mathrm{~min}$ at $95^{\circ} \mathrm{C}$ (Polymerase activation step) followed by 45 cycles of $95^{\circ} \mathrm{C}$ for 15 seconds (DNA-dissociation) and $60^{\circ} \mathrm{C}$ for one minute (Annealing and elongation).

\section{Efficiency and sensitivity}

Prior to real-time RT PCR analysis the VHS virus assay was optimized with regards to concentrations of primers and probe. An efficiency test was preformed to test the efficiency of the VHS virus and elongation factor assays in order to be able to perform relative quantification of the amount of VHS virus in the samples. This test was performed by using a tenfold dilution series. The dilution series was made in the concentration ranging from $477.6 \mathrm{ng} / \mu \mathrm{l}$ to $4.776^{-06} \mathrm{ng} / \mu \mathrm{l}$ for VHS virus assay and $243.6 \mathrm{ng} / \mu \mathrm{l}$ to $2.436^{-06} \mathrm{ng} / \mu \mathrm{l}$ for the elongation factor assay. Template used in the efficiency test was as described above. The dilution series was analyzed in triplicates using one-step real-time RT PCR. The mean Ct value for each triplicate was calculated and a standard curve was made by plotting $\mathrm{Ct}$ values against the serial logarithmic dilutions. The amplification efficiency (E) for the VHSV08 and EF1A assays were calculated using the formula: $\left(10^{-1 / \text {-slope }}\right)-1$ and were found to be $E=0,98394$ and $E=0,8952$, respectively.

Table 6 Real time PCR assays for VHS virus, Paranucleospora theridion, Flavobacterium psychrophilum, Candidatus Piscichlamydia salmonis and a new species of chlamydia from gills of Atlantic salmon.

\begin{tabular}{|c|c|c|c|c|}
\hline Target & Code: & Primers/probe & Amplicon size & Reference \\
\hline \multirow[t]{3}{*}{ VHS virus } & VHSV F08 & TGT CCG TKC TTC TCT CCT ATG TAC T & & Modified \\
\hline & VHSV probe & CTC ACA GAC ATG GG & $109 \mathrm{nt}$ & {$[44]$} \\
\hline & VHSV R08 & GCC CTG RCT GMC TGT GTC A & & Modified \\
\hline Paranucleospora & PT-F & CGG ACA GGG AGC ATG GTA TAG & & \\
\hline \multirow[t]{2}{*}{ theridion } & PT-probe & TTG GCG AAG AAT GAA A & $59 \mathrm{nt}$ & {$[49]$} \\
\hline & PT-R & GGT CCA GGT TGG GTC TTG AG & & \\
\hline Flavobacterium & Flavo-R & TGT AAA CTG CTT TTG CAC AGG AA & & \\
\hline \multirow[t]{2}{*}{ psychrophilum } & Flavo-probe & AAA CAC TCG GTC GTG ACC & $72 \mathrm{nt}$ & Present study \\
\hline & Flavo-F & GAT CCT TAT TCT CAC AGT ACC GTC AA & & \\
\hline Candidatus & Pch-F & TCA CCC CCA GGC TGC Tा & & \\
\hline Piscichlamydia & Pch-probe & CAA AAC TGC TAG ACT AGA GT & $60 \mathrm{nt}$ & Present study \\
\hline salmonis & Pch-R & GAA TTC CAT TTC CCC CTC TTG & & \\
\hline New species of & Sch-F & GGG TAG CCC GAT ATC TTCA AAG T & & \\
\hline \multirow[t]{2}{*}{ gill chlamydia } & Sch-probe & TCC TTC GGG ACC TTA C & $66 \mathrm{nt}$ & Present study \\
\hline & Sch-R & CCC ATG AGC CGC TCT CTC T & & \\
\hline Elongation factor & EL1A-elaf & CCC CTC CAG GAC GTT TAC AAA & & \\
\hline 1 alpha & EL1A-elam1 & ATC GGT GGT ATT GGA AC & $57 \mathrm{nt}$ & {$[45]$} \\
\hline S. salar & EL1A-elar & CAC ACG GCC CAC AGG TAC A & & \\
\hline
\end{tabular}


To perform the sensitivity test a twofold dilution series was made from $0,4 \mathrm{ng} / \mu \mathrm{l}$ to $0,0625 \mathrm{ng} / \mu \mathrm{l} .10 \mathrm{repli}$ cates were made from each dilution and analyzed using one-step real time PCR. The sensitivity limit of the VHSV08 assay was set as the highest dilution where all 10 replicates were positive. The detection limit, derived from this sensitivity test for the VHSV08 assay, was found to be $\mathrm{Ct}=37.0$. This implies that $\mathrm{Ct}$ values higher than this limit may not be reproducible.

\section{Relative quantification}

The expression of the target VHS virus genome template was calculated using the formula for normalized expression $(\mathrm{NE}): \mathrm{NE}=\left(\mathrm{E}_{\text {reference }}\right)^{\mathrm{Ct}}$ reference $/\left(\mathrm{E}_{\text {target }}\right)^{\mathrm{Ct}}$ target, where $\mathrm{E}=$ amplification efficiency.

\section{Phylogenetic analysis}

The nearly complete genome of the VHS virus isolate, FA28.11.07, from the farmed rainbow trout kept in Storfjorden western Norway, was sequenced (Accession no. EU481506). The $\mathrm{N}$ and $\mathrm{G}$ protein genes were aligned with homologous gene sequences from a selected number of VHS viruses already available on the EMBL nucleotide database, including a Norwegian isolate collected from rainbow trout in 1968 (Accession no: AY546621). The VHS virus (CH18.03.08) from herring (Accession nos: FJ384761, GU066860), collected in the outlet of the fjord, was also included in the analysis. To perform pairwise comparisons between the different viruses, the multiple sequence alignment editor GeneDoc (Available at: http:// www.psc.edu/biomed/genedoc) was used. Polymorphic regions were manually aligned and compared for both genes. Gaps in the alignment were deleted (the alignment can be obtained from the corresponding author).

Phylogenetic analyses of the data sets were performed using PAUP* version 4.0 [46] and TREE-PUZZLE 5.2 (Available at: http://www.tree-puzzle.de). TREE-PUZZLE reconstructs phylogenetic trees from molecular data by maximum likelihood, and computes maximum likelihood distances and branch lengths. A model corresponding to GTR + I was identified by the Akaike information criterion using the Modeltest 3.6 script [47] in PAUP v4.0 [46], to be suitable for the datasets. In this study 10000 quartet puzzling $(\mathrm{QP})$ steps were carried out. The QP tree search estimates support values for each internal branch. Branches showing QP reliability from $90-100 \%$ can be considered very strongly supported. Branches with lower reliability $(>70 \%)$ can in principle be trusted. The only phylogeny presented in this study is the result of analysis using the GTR matrix in TREE-PUZZLE. Phylogenetic trees were drawn using TreeView [48].

\section{Authors' contributions}

AN conceived the study. AN, HD and SN planned the experimental design. $\mathrm{AN}, \mathrm{HD}$ and $\mathrm{SN}$ carried out the challenge experiment and sampling. SN cultured the virus and did all the sequencing. HD analyzed all samples. KW did the processing for histology and $\mathrm{AN}$ and $\mathrm{KW}$ did the histological examinations. KFO sampled the field material and helped with the processing and analyzing of this material. AN and HD drafted the manuscript. All authors critically reviewed and approved the final manuscript.

\section{Competing interests}

The authors declare that they have no competing interests.

\section{Received: 27 October 2009}

Accepted: 26 January 2010 Published: 26 January 2010

\section{References}

1. Knipe DM, Howley PM: Fields Virology. Lippincott Williams \& Wilkins, Philadelphia 2001.

2. Benmansour A, Basurco B, Monnier AF, Vende $P$, Winton JR, de Kinkelin P: Sequence variation of the glycoprotein gene identifies three distinct lineages within field isolates of viral haemorrhagic septicaemia virus, a fish rhabdovirus. J Gen Virol 1997, 78:2837-2846.

3. Einer-jensen $K$, Ahrens P, Forsberg R, Lorenzen N: Evolution of the fish rhabdovirus viral haemorrhagic septicaemia virus. J Gen Virol 2004, 85:1167-1179.

4. Nishizawa T, lida H, Takano R, Isshiki T, Nakajima K, Muroga K: Genetic relatedness among Japanese, American and European isolates of viral hemorrhagic septicemia virus (VHSV) based on partial G and P genes. Dis Aquat Org 2002, 48(2):143-148.

5. Snow M, Bain N, Black J, Taupin V, Cunningham CO, King JA, Skall HF, Raynard RS: Genetic population structure of marine viral haemorrhagic septicaemia virus (VHSV). Dis Aquat Org 2004, 61(1-2):11-21.

6. Stone DM, Way K, Dixon PF: Nucleotide sequence of the glycoprotein gene of viral haemorrhagic septicaemia (VHS) viruses from different geographical areas: A link between VHS in farmed fish species and viruses isolated from North Sea cod (Gadus morhua L). J Gen Virol 1997, 78:1319-1326.

7. Thiery R, de Boisseson C, Jeffroy J, Castric J, de Kinkelin P, Benmansour A: Phylogenetic analysis of viral haemorrhagic septicaemia virus (VHSV) isolates from France (1971-1999). Dis Aquat Org 2002, 52(1):29-37.

8. Skall HF, Olesen NJ, Mellergaard S: Viral haemorrhagic septicaemia virus in marine fish and its implications for fish farming - a review. J Fish Dis 2005, 28(9):509-529.

9. Dale OB, Ørpetveit I, Lyngstad TM, Kahns S, Skall HF, Olesen NJ, Dannevig BH: Outbreak of viral haemorrhagic septicaemia (VHS) in seawater-farmed rainbow trout in Norway caused by VHS virus Genotype III. Dis Aquat Org 2009, 85:93-103.

10. Duesund $\mathrm{H}$ : Experimental challenge of rainbow trout (Oncorhychus mykiss) using a Viral haemorrhagic septicaemia virus (VHSV) isolate, genotype III, collected from farmed rainbow trout at a marine site on the west coast of Norway. Master thesis University of Bergen 2008, 59.

11. Lopez-Vazquez C, Raynard RS, Bain N, Snow M, Bandin I, Dopazo CP: Genotyping of marine viral haemorrhagic septicaemia virus isolates from the Flemish Cap by nucleotide sequence analysis and restriction fragment length polymorphism patterns. Dis Aquat Org 2006, 73:23-31.

12. Skall HF, Slierendrecht WJ, King JA, Olesen NJ: Experimental infection of rainbow trout Oncorhynchus mykiss with viral haemorrhagic septicaemia virus isolates from European marine and farmed fishes. Dis Aquat Org 2004, 58(2-3):99-110.

13. King JA, Snow M, Smail DA, Raynard RS: Experimental susceptibility of Atlantic salmon Salmo salar and turbot Scophthalmus maximus to European freshwater and marine isolates of viral haemorrhagic septicaemia virus. Dis Aquat Org 2001, 47(1):25-31.

14. Snow M, King JA, Garden A, Shanks AM, Raynard RS: Comparative susceptibility of turbot Scopthalmus maximus to different genotypes of viral haemorrhagic septicaemia virus. Dis Aquat Org 2005, 67:31-38.

15. Snow M, Smail DA: Experimental susceptibility of turbot Scophthalmus maximus to viral haemorrhagic septicaemia virus isolated from cultivated turbot. Dis Aquat Org 1999, 38(3):163-168.

16. Bowden TJ: A study of the susceptibility of Atlantic halibut, Hippoglossus hippoglossus (L.), to viral haemorrhagic septicaemia virus isolated from turbot, Scophthalmus maximus (L.). J Fish Dis 2003, 26(4):207-212. 
17. Nylund A, Alexandersen $S$, Løvik $P$, Jakobsen $P$ : The response of brown trout (Salmo trutta L.) to repeated challenge with infectious salmon anaemia (ISA). Bull Eur Ass Fish Pathol 1994, 14:167-170.

18. Nylund $A$, Jakobsen $P$ : Sea trout as a carrier of infectious salmon anaemia virus. J Fish Biol 1995, 47:174-176.

19. Betts AM, Stone DM: Nucleotide sequence analysis of the entire coding regions of virulent and avirulent strains of viral haemorrhagic septicaemia virus. Virus Genes 2000, 20(3):259-262.

20. Schütze $H$, Mundt $E$, Mettenleiter TC: Complete genomic sequence of Viral Hemorrhagic Septicemia virus, a fish rhabdovirus. Virus Genes 1999, 19:59-65.

21. Poch O, Blumberg BM, Bougueleret $L$, Tordo $N$ : Sequence comparison of five polymerases ( $L$ proteins) of unsegmented negative-strand RNA viruses: Theoretical assignment of functional domains. J Gen Virol 1990, 71:1153-1162.

22. Gaudin Y, Kinkelin P, Benmansour A: Mutations in the glycoprotein of viral haemorrhagic septicaemia virus that affect virulence for fish and the $\mathrm{pH}$ threshold for membrane fusion. J Gen Virol 1999, 80:1221-1229.

23. Alonso M, Kim CH, Johnson MC, Pressley M, Long JA: The NV gene of snakehead rhabdovirus (SHRV) is not required for pathogenesis, and a heterologous glycoprotein can be incorporated into the SHRV envelope. J Vir 2004, 78:5875-5882

24. Kim DH, Oh HK, Eou Jl, Seo HJ, Kim SK, Oh MJ, Nam SW, Choi TJ: Complete nucleotide sequence of the Hirame rhabdovirus a pathogen of marine fish. Virus Res 2005, 107:1-9.

25. Schütze H, Enzmann PJ, Kuchling R, Mundt E, Niemann H, Mettenleiter TC: Complete genomic sequence of the fish rhabdovirus infectious haematopoietic necrosis virus. J Gen Virol 1995, 76:2519-2527.

26. Brudeseth $B E$, Evensen $\varnothing$ : Occurrence of viral haemorrhagic septicaemia virus (VHSV) in wild marine fish species in the coastal regions of Norway. Dis Aquat Org 2002, 52:21-28.

27. Mortensen HF, Heuer OE, Lorenzen N, Otte L, Olesen NJ: Isolation of viral haemorrhagic septicaemia virus (VHSV) from wild marine fish species in the Baltic Sea, Kattegat, Skagerrak and the North Sea. Virus Res 1999, 63(1-2):95-106.

28. Smail DA: Isolation and identification of viral haemorrhagic septicaemia (VHS) viruses from cod Gadus morhua with the ulcus syndrome and from haddock Melenogrammus aeglefinus having skin haemorrhages in the North Sea. Dis Aquat Org 2000, 41:231-235.

29. Manrubia SC, Lázaro E: Viral evolution. Physics of Life Reviews 2006, 3(2):65-92.

30. Brudeseth BE, Skall HF, Evensen $\varnothing$ : Differences in virulence of marine and freshwater isolates of viral hemorrhagic septicemia virus in vivo correlate with in vitro ability to infect gill epithelial cells and macrophages of rainbow trout (Oncorhynchus mykiss). J Virol 2008, 82(21):10359-10365.

31. Dixon PF, Feist S, Kehoe E, Parry L, Stone DM, Way K: Isolation of viral haemorrhagic septicaemia virus from Atlantic herring Clupea harengus from the English Channel. Dis Aquat Org 1997, 30:81-89.

32. Raja-Halli M, Vehmas TK, Rimaila-Pärnänen $E$, Sainmaa S, Skall HF, Olesen NJ, Tapiovaara H: Viral haemorrhagic septicaemia (VHS) outbreaks in Finnishrainbow trout farms. Dis Aquat Org 2006, 72(3):201-211.

33. Brudeseth BE, Raynard RS, King JA, Evensen $\varnothing$ : Sequential pathology after experimental infection with marine viral hemorrhagic septicaemia virus isolates of low and high virulence in turbot (Scopthalmus maximus L.). Vet Pathol 2005, 42:9-18.

34. Lopez-Vazquez C, Dopazo CP, Barja JL, Bandin I: Experimental infection of turbot, Psetta maxima (L.), with strains of viral haemorrhagic septicaemia virus isolated from wild and farmed marine fish. J Fish Dis 2007, 30:303-312.

35. Snow M, King JA, Garden A, Raynard RS: Experimental susceptibility of Atlantic cod, Gadus morhua (L.), and Atlantic halibut, Hippoglossus hippoglossus (L.), to different genotypes of viral haemorrhagic septicaemia virus. J Fis Dis 2005, 28(12):737-742

36. Wolf K: Viral hemorrhagic septicemia. Fish Viruses and Fish Viral Diseases Ithaca and London, Comstock Publishing Associates, Cornell University PressWolf K 1988, 217-249.

37. Chico V, Gomez N, Estepa A, Perez L: Rapid detection and quantitation of viral hemorrhagic septicemia virus in experimentally challenged rainbow trout by real-time RT-PCR. J Virol Methods 2006, 132(1-2):154-159.
38. Snow M, Cunningham CO: Virulence an nucleotide sequence analysis of marine viral haemorrhagic septicaemia virus following in vivo passage in rainbow trout Oncorhynchus mykiss. Dis Aquat Org 2000, 42:17-26.

39. Elsayed E, Faisai M, Thomas M, Whelan G, Batts W, Winton J: Isolation of viral haemorrhagic septicaemia virus from muskellunge, Esox masquinongy (Mitchill), in lake St Clair, Michigan, USA reveals a new sublineage of the North American genotype. J Fish Dis 2006, 29:611-619.

40. Bols NC, Barlian A, Chirino-Trejo M, Caldwell SJ, Goegan P, Lee LEJ: Development of a cell line from primary cultures of rainbow trout, Oncorhynchus mykiss (Walbaum), gills. J Fish Dis 1994, 17:602-611.

41. Devold M, Krossøy B, Aspehaug V, Nylund A: Use of RT-PCR for diagnosis of infectious salmon anaemia virus (ISAV) in carrier sea trout Salmo trutta after experimental infection. Dis Aquat Org 2000, 40:9-18.

42. Miller TA, Rapp J, Wastlhuber U, Hoffmann RW, Enzmann PJ: Rapid and sensitive reverse transcriptase polymerase chain reaction based detection and differential diagnosis of fish pathogenic rhabdoviruses in organ samples and cultured cells. Dis Aquat Org 1998, 34:13-20.

43. Giovannoni S: The polymerase chain reaction. Nucleic acid techniques in bacterial systematics John Wiley and Sons, New YorkStackebrandt E, Goodfellow M 1991, 177-201.

44. Matejusova I, McKay P, McBeath AJA, Collet B, Snow M: Development of a sensitive and controlled real-time RT-PCR assay for viral haemorrhagic septicaemia virus (VHSV) in marine salmonid aquaculture. Dis Aquat Org 2008, 80:137-144.

45. Olsvik PA, Lie KK, Jordal AE, Nilsen TO, Hordvik I: Evaluation of potential reference genes in real-time RT-PCR studies of Atlantic salmon. BMC Molecular Biology 2005, 6(21):1-9.

46. Swofford DL: Phylogenetic analysis using parsimony and other methods, version 4.0. Sinauer Associates, Sunderland 1998

47. Posada D, Crandall KA: Modeltest: testing the model og DNA substitution. Bioinformatics Application note 1998, 14(9):817-818.

48. Page RDM: TreeView: An application to display phylogenetic trees on personal computers. Computer Applications in the Biosciences 1996, 12:357-358.

49. Nylund S, Nylund A, Watanabe K, Arnesen CE, Karlsbakk E: Paranucleospora theridion n.gen., n. sp. (Microsporidia, Enterocytozoonidae) with a life cycle in the salmon louse (Lepeophtheirus salmonis, Copepoda) and Atlantic salmon (Salmo salar). J Eukaryot Microbiol 2010, E-pub.

doi:10.1186/1743-422X-7-19

Cite this article as: Duesund et al:: Characterization of a VHS virus genotype III isolated from rainbow trout (Oncorhychus mykiss) at a marine site on the west coast of Norway. Virology Journal 2010 7:19.
Publish with Bio Med Central and every scientist can read your work free of charge

"BioMed Central will be the most significant development for disseminating the results of biomedical research in our lifetime. "

Sir Paul Nurse, Cancer Research UK

Your research papers will be:

- available free of charge to the entire biomedical community

- peer reviewed and published immediately upon acceptance

- cited in PubMed and archived on PubMed Central

- yours - you keep the copyright
BioMedcentral 